\title{
Comparing the role of accruals and operating cash flows on users' decisions on financial statements: A case study of Tehran Stock Exchange
}

\author{
Mohsen Sohrabi Araghi ${ }^{\mathrm{a}}$ and Sharifaldin Attari ${ }^{\mathrm{b}^{*}}$
}

${ }^{a}$ Department of Accounting, School of Management, Tehran North Branch, Islamic Azad University (IAU), Tehran, Iran ${ }^{b}$ M.Sc. Student, Department of Accounting, School of Management, Tehran North Branch, Islamic Azad University (IAU), Tehran, Iran

\section{H R O N I C LE A B T T A C T}

Article history:

Received June 2, 2012

Received in revised format

28 October 2012

Accepted 7 November 2012

Available online

November 92012

Keywords:

Accruals

Information content

Operating cash flows

Financial ratios

Profit

Jones model

Information value-added

\begin{abstract}
One of the major challenges facing all of individuals and organizations is decision-making based on the information. The issues of priority about cash flows and accruals data in decisionmaking process for different groups of financial statement users include investors, creditors, shareholders, directors, etc. one of the issues that has been controversial between accrual and cash accounting advocators for a long time. In this study, we survey the role of accruals and operating cash flows in decisions of financial statement users in listed companies on Tehran stock exchange, information content of operating cash flows and accruals in the connection with decision-making criteria used by different groups using financial statement has been examined. In this study, we use eliminating sampling and implied limitations and the sample size includes 203 companies to examine six hypotheses. The results of this research indicate that there is a significant different between accruals and operating cash flows information content in relation to various decision-making criteria but utilizing accruals and operating cash flows supplementary and simultaneously in profit frame depending on the selection criteria may or may not be include information value-added.
\end{abstract}

\section{Introduction}

One of the major challenges facing all of individuals and organizations is decision-making based on the information. The issue of priority about cash flows and accruals data in decision-making process for different groups of financial statement users include investors, creditors, shareholders, directors etc. In this study, we study the role of accruals and operating cash flows in decisions of financial statement users in listed companies on Tehran stock exchange, information content of operating cash flows and accruals in the connection with decision-making criteria used by different groups using financial statement has been examined. 
Panahian et al. (2008) presented an investigation to detect the relationship between discretionary accruals quality as well as innate accruals quality and portion of non-executive board of directors, concentration of ownership ratio and board size in Tehran Stock Exchange. The study used two linear regression models to estimate the first part of the information and then using structural equation modeling examined six hypotheses. Based on the results of this survey they concluded that an increase on non-executive members positively could impact on discretionary accruals quality and negatively affected innate accruals quality. They also reported that concentration of ownership ratio positively impacted on discretionary accruals quality and negatively influenced on innate accruals quality. Finally, size of board of directors negatively impacted discretionary accruals quality and positively impacted on innate accruals quality.

Khodaei Valahzaghard and Salehi (2012) studied corporate governance and ownership impacts on earning quality in Iranian private banks. The study implemented the information of 12 private banks over the period 2005- 2010 based on regression analysis using some panel data. Among various factors, the impact of big five shareholder were investigated to be significant and positive on earning quality. Besides, the impact of one variable regression test disclosed that institutional ownership had positive influence on earning quality. However, the effects of other variables including percentage of ownership concentration, the size of board of directors, reliance on debt, logarithm of sum of assets, return of assets, logarithm of operating cash flow on earning quality were not significance. They concluded that institutional ownership had important impact on earning quality simply since institutions normally had the access on professionals to control management.

Hassani and Taheri (2012) investigated the impact of earnings management and dividend announcement in explanation of information asymmetry. The study only implemented qualified samples by taking into account all limitations and necessary criteria. Based on the results of this survey, they concluded that there was not a meaningful relationship between earning management and information asymmetry in Tehran Stock Exchange. There was also not a meaningful relationship between low or high earning management and information asymmetry. Estimated dividend announcement had some data content and it could impact on information asymmetry.

Rezaei et al. (2012) studied the effect of board of directors on the rate of corporate transparency. They considered the impact of the combination of board of directors on the corporate transparency in some firms in Tehran Stock Exchange Market over the period of 2007- 2010. In this research, the combination of board of directors was selected among some factors of corporate transparency such as structure of ownership and the rights of owners, financial information and statistics and structure and combination of board of directors and managers as a sub-indicator for corporate governance. Linear regression statistical method was implemented to examine different hypotheses of study. They concluded that the members of board of directors had no impact on partnership transparency, but impacted on financial data and information and structure and combination of board of directors.

Arabzadeh (2012) performed an investigation on the effects of cost-of-equity models on cost-ofcapital and capital structure. They studied effective factors on such models on Tehran stock exchange based on some data over the period 2001-2005. The study analyzed and tested important data to firm's debt ratio and corporate size as efficient factors on cost-of-equity. The preliminary findings indicated that contrary to the commonly held belief in financial management theorems, debts ratio had the least impact on cost-of-equity. Nevertheless, the study suggested that the variant of company's size had a meaningful relationship with cost-of-equity. To calculate cost-of-equity, CAPM, Gordon and return ratio methods were implemented and the results indicated that CAPM had more validity compared with other varieties. On the other hand, the results indicated that there was a 95-percent probability proving that liquidity had a significant negative impact on financial leverage. 
Raei and Bahrani Jahromi (2012) developed a model for portfolio optimization using a hybrid of fuzzy ANP, VIKOR and TOPSIS in Tehran Stock Exchange. The results of the implementation of the proposed model had been examined against Markowitz traditional model and the preliminary results indicated that the proposed model of their method performed reasonably well compared with alternative method. VakilAlroaia et al. (2012) investigated the relationship between forwardbackward impacts on stock return, which normally depends on Price-Earnings ratio (P/E) and stock fluctuation in stock exchange. They used monthly time series pattern of Tehran stock exchange over the period of 2006-2010. The data contained all available companies in exchange where the shares were traded at the least 120 days during for the recent 12 months. They reported that the independent variables investigated in this research had meaningful impacted on the research's dependent variable. This means that the impacts of company's systematic risk and markets risk on companies' stock return are positive.

\section{The proposed model}

The proposed study of this paper uses the historical information of stocks traded on Tehran Stock Exchange over the period 2001-2009. In our survey, we consider four major criteria for picking the stocks, which are as follows,

1. Firm must be tradable before year 2001 and it must have been actively traded during the years of study.

2. Firm should not have changed their fiscal year during the period of study.

3. No holding or investment companies are permitted in this survey.

4. All necessary information must be available.

Based on these criteria, we could determine 203 firms for the proposed study of this research and using 1421 year-firm from 24 different industries, the proposed study of this paper considers six hypotheses. Table 1 shows details of independent and dependent variables,

\section{Table 1}

Details of dependent and independent variables

\begin{tabular}{llll}
\hline Symbol & Variable & Method for calculation & Variable type \\
\hline EPS $_{\mathrm{t}}$ & Earning per share & Net revenue divided by the number of shares & Dependent \\
GPRFT $_{\mathrm{t}}$ & Growth profit & Revenue - Cost & Independent \\
$\mathrm{OI}_{\mathrm{t}}$ & Operating profit & Growth profit - operating expenses & Independent \\
$\mathrm{NI}_{\mathrm{t}}$ & Net income & Operating profit - non-operating expenses - Tax & Independent \\
TACC $_{\mathrm{t}}$ & Total Accruals & Calculated based on balance sheet information & Independent \\
$\mathrm{OCF}_{\mathrm{t}}$ & Operating cash flow & Input cashflows -output cashflows & Independent \\
ROS $_{\mathrm{t}}$ & Sale's margin & Net profit divided by net sale & Independent \\
CURRENTRATIO $_{\mathrm{t}}$ & Current ratio & Current assets divided by current liabilities & Independent \\
CASHCYCLE $_{\mathrm{t}}$ & Cash cycle & 365 divided by receivable cash & Independent \\
DEBTRATIO $_{\mathrm{t}}$ & Debt ratio & Total liabilities divided by total assets & Independent \\
$(\mathrm{P} / \mathrm{E})_{\mathrm{t}}$ & Price per earning ratio & Share price divided by earning per share & Independent \\
\hline
\end{tabular}

There are two methods for calculating TACC based on balance sheet and statement. The first method, balance sheet based, is as follows,

$$
T_{A C C_{i t}}=\left(\Delta C A_{i t}-\triangle C A S H_{i t}\right)-\left(\Delta C L_{i t}-\triangle S T D E B T_{i t}\right)-D E P T N_{i t} .
$$

In addition, statement based method uses the following method,

$$
\mathrm{TACC}_{i t}=\mathrm{EBXT}_{i t}-O C F_{i t} \text {. }
$$


In Eq. (1) and Eq. (2), $E B X T_{i t}$ is net profit before deducting unexpected cost, $O C F_{i t}$ is operating cash flow for, $C A_{i t}$ represents current assets, $C A S H_{i t}$ is total cash or its equivalent, $C L_{i t}$ is total liabilities, $S T D E B T_{i t}$ is long term liabilities, $D E P T N_{i t}$ is the cost of depreciation of fixed or intangible assets for firm $i$ in year $t$. Next, we present details of all six hypotheses as well as econometrics methods for validating them.

\section{The results}

In this section, we present details of our findings on various hypotheses associated with the proposed study of this paper.

\subsection{The first hypothesis}

There is one main hypothesis, which is as follows,

$\mathrm{H}_{0}$ : There is no meaningful relationship between total accruals and total operating cash flow.

$\mathrm{H}_{1}$ : There is a meaningful relationship between total accruals and total operating cash flow.

Table 2 shows the proposed econometrics method as well as the results of our study using the implementation of ordinary least square.

Table 2

The results of regression model and the results of regression analysis for the first hypothesis

\begin{tabular}{|c|c|c|c|c|c|c|c|}
\hline \multirow{3}{*}{$\begin{array}{l}\text { Model } \\
\text { Variables } \\
\end{array}$} & \multicolumn{7}{|c|}{$E P S_{t}=\beta_{0}+\beta_{1} G P R F T_{t}+\beta_{2} O I_{t}+\beta_{3} N I_{t}+\beta_{4} O C F_{t}+\beta_{5} T A C C_{t}+\varepsilon_{t}$} \\
\hline & \multicolumn{2}{|c|}{ Colinearlity } & \multicolumn{2}{|c|}{ Coefficient } & \multicolumn{3}{|c|}{ Statistical tests } \\
\hline & VIF & Tolerance & Non-standard & Standard & Standard error & t-student & P-value \\
\hline Constant & & & 899.035 & & 101.510 & 8.857 & 0.000 \\
\hline GPRFT & 1.144 & 0.874 & 15.829 & 0.390 & 1.255 & 6.240 & 0.005 \\
\hline OI & 1.527 & 0.655 & 17.680 & 0.184 & 6.941 & 2.547 & 0.000 \\
\hline NI & 1.631 & 0.613 & 132.408 & 0.637 & 15.503 & 8.541 & 0.000 \\
\hline OCF & 1.328 & 0.753 & 14.365 & 0.541 & 5.321 & 7.543 & 0.000 \\
\hline TACC & 1.174 & 0.852 & 12.245 & 0.023 & 4.237 & 3.441 & 0.016 \\
\hline Auto-correlation & & & & & & Regressic & \\
\hline Durbin-Watson & $\mathrm{R}^{2}$ & Adjusted $\mathrm{R}^{2}$ & & Standard & & $\mathrm{F}$ & P-value \\
\hline 1.929 & 0.840 & 0.830 & & 65.92795 & & 82.160 & 0.000 \\
\hline
\end{tabular}

Based on the results of Table 2, we can understand that F-value lies within the acceptable limit and we can conclude that there is a linear relationship between independent variables and dependent variable. In addition, t-student value is statistically meaningful, which means we can reject the null hypothesis and Durbin-Watson remains within an acceptable limit leaving us to conclude that there is no auto correlation between residuals. Both OCF and TACC maintain positive relationship with EPS, which is what we expected and we conclude that there is meaningful relationship between total accrual and operating cash flow.

$\mathrm{H}_{0}$ : There is no meaningful relationship between EPS and a combination of total accruals and total operating cash flow.

$\mathrm{H}_{1}$ : There is a meaningful relationship between EPS and a combination of total accruals and total operating cash flow. 
As we can observe from the results of Table 2, the coefficients associated with growth profit, operating profit and net earnings are equal to 15.829, 17.680 and 132.408, respectively. Since all profit components include two components of cash and accrual and they are greater than independent components of cash (14.365) and accrual (12.245) associated with earning per share, we can reject the null hypothesis and conclude that both cash and accrual terms together contribute to EPS.

\subsection{The second hypothesis}

There is a main hypothesis, which is as follows,

$\mathrm{H}_{0}$ : There is no meaningful relationship between the information obtained from total accruals compared with and total operating cash flow in relationship with sales' margin.

$\mathrm{H}_{1}$ : There is a meaningful relationship between the information obtained from total accruals compared with total operating cash flow in relationship with sales' margin.

Table 3 demonstrates the proposed econometrics method as well as the results of our study using the implementation of ordinary least square.

\section{Table 3}

The results of regression model and the results of regression analysis for the second hypothesis

\begin{tabular}{|c|c|c|c|c|c|c|c|}
\hline Model & \multicolumn{7}{|c|}{$R O S_{t}=\beta_{0}+\beta_{1} G P R F T_{t}+\beta_{2} O I_{t}+\beta_{3} N I_{t}+\beta_{4} O C F_{t}+\beta_{5} T_{A C C_{t}}+\varepsilon_{t}$} \\
\hline Variables & \multicolumn{2}{|c|}{ Colinearlity } & \multicolumn{2}{|c|}{ Coefficient } & \multicolumn{3}{|c|}{ Statistical tests } \\
\hline & VIF & Tolerance & Non-standard & Standard & Standard error & t-student & P-value \\
\hline Constant & & & 776.046 & & 28.513 & 3.009 & 0.004 \\
\hline GPRFT & 1.550 & 0.645 & 71.591 & 0.173 & 16.092 & 4.477 & 0.000 \\
\hline $\mathrm{OI}$ & 1.195 & 0.837 & 32.871 & 0.471 & 7.323 & 7.904 & 0.000 \\
\hline NI & 1.468 & 0.681 & 44.664 & 0.161 & 8.413 & 4.216 & 0.022 \\
\hline OCF & 1.531 & 0.653 & 29.286 & 0.152 & 7.941 & 4.083 & 0.000 \\
\hline TACC & 1.812 & 0.552 & 31.662 & 0.382 & 3.884 & 6.231 & 0.016 \\
\hline Auto-correlation & & & & & & Regressic & \\
\hline Durbin-Watson & $\mathrm{R}^{2}$ & Adjusted I & & Standard & & $\mathrm{F}$ & P-value \\
\hline 1.791 & 0.762 & 0.753 & & 32.61681 & & 17.502 & 0.006 \\
\hline
\end{tabular}

Based on the results of Table 3, we can understand that F-value lies within the acceptable limit and we can conclude that there is a linear relationship between independent variables and dependent variable. In addition, t-student value is statistically meaningful, which means we can reject the null hypothesis and Durbin-Watson (1.791) remains within an acceptable limit leaving us to conclude that there is no auto correlation between residuals. The coefficient of accrual is 31.662, which is greater than the coefficient of operating cash flow (29.286), which means that there is a meaningful different between accrual and operating cash flow for describing sales' margin. Therefore, we can reject the null hypothesis. Both OCF and TACC maintain positive relationship with EPS, which is what we expected and we can conclude that there is meaningful relationship between total accrual and operating cash flow.

$\mathrm{H}_{0}$ : There is no meaningful relationship between simultaneous use of total accruals and total operating cash flow and sales' margin.

$\mathrm{H}_{1}$ : There is no meaningful relationship between simultaneous use of total accruals and total operating cash flow and sales' margin. 
As we can observe from the results of Table 3, the coefficients associated with growth profit, operating profit and net earning are equal to 71.591, 32.871 and 44.664, respectively. Since all profit components include two components of cash and accrual and they are greater than independent components of cash (29.286) and accrual (31.662) associated with earning per share, we can reject the null hypothesis and conclude that both cash and accrual terms together contribute to sales' margin.

\subsection{The third hypothesis}

There is a main hypothesis, which is as follows,

$\mathrm{H}_{0}$ : There is no meaningful relationship between the information obtained from total accruals compared with and total operating cash flow in relationship with current ratio.

$\mathrm{H}_{1}$ : There is a meaningful relationship between information obtained from total accruals compared with total operating cash flow in relationship with current ratio.

Table 4 demonstrates the proposed econometrics method as well as the results of our study using the implementation of ordinary least square.

\section{Table 4}

The results of regression model and the results of regression analysis for the third hypothesis

\begin{tabular}{lllllll}
\hline \multicolumn{2}{l}{ Model CURRENTRATIO } \\
\hline
\end{tabular}

Based on the results of Table 4, we can understand that F-value lies within the acceptable limit and we can conclude that there is a linear relationship between independent variables and dependent variable. In addition, t-student value is statistically meaningful, which means we can reject the null hypothesis and Durbin-Watson (1.842) remains within an acceptable limit leaving us to conclude that there is no auto correlation between residuals. The coefficient of accrual is 89.331, which is greater than the coefficient of operating cash flow (14.112), which means that there is a meaningful different between accrual and operating cash flow for describing current ratio. Therefore, we can reject the null hypothesis.

$\mathrm{H}_{0}$ : There is no meaningful relationship between simultaneous use of total accruals and total operating cash flow and current ratio.

$\mathrm{H}_{1}$ : There is no meaningful relationship between simultaneous use of total accruals and total operating cash flow and current ratio.

As we can observe from the results of Table 4, the coefficients associated with growth profit, operating profit and net earnings are equal to 7.485, 7.452 and 13.110, respectively. Since all profit 
components include two components of cash and accrual and they are greater than independent components of cash (14.112) and accrual (89.331) associated with earning per share, we can reject the null hypothesis and conclude that both cash and accrual terms to gether contribute to current ratio.

\subsection{The fourth hypothesis}

There is a main hypothesis, which is as follows,

$\mathrm{H}_{0}$ : There is no meaningful relationship between the information obtained from total accruals compared with and total operating cash flow in relationship with cash cycle.

$\mathrm{H}_{1}$ : There is a meaningful relationship between information obtained from total accruals compared with total operating cash flow in relationship with cash cycle.

Table 5 demonstrates the proposed econometrics method as well as the results of our study using the implementation of ordinary least square.

\section{Table 5}

The results of regression model and the results of regression analysis for the fourth hypothesis

\begin{tabular}{|c|c|c|c|c|c|c|c|}
\hline \multicolumn{8}{|c|}{ Model CASHCYCLE $E_{t}=\beta_{0}+\beta_{1} G P R F T_{t}+\beta_{2} O I_{t}+\beta_{3} N I_{t}+\beta_{4} O C F_{t}+\beta_{5} T A C C_{t}+\varepsilon_{t}$} \\
\hline \multirow[t]{2}{*}{ Variables } & \multicolumn{2}{|c|}{ Colinearlity } & \multicolumn{2}{|c|}{ Coefficient } & \multicolumn{3}{|c|}{ Statistical tests } \\
\hline & VIF & Tolerance & Non-standard & Standard & Standard error & t-student & P-value \\
\hline Constant & & & 287.981 & & 52.560 & 5.479 & 0.000 \\
\hline GPRFT & 1.835 & 0.545 & 7.634 & 0.107 & 2.223 & 3.176 & 0.013 \\
\hline OI & 1.067 & 0.937 & 21.423 & 0.328 & 14.543 & 7.335 & 0.040 \\
\hline NI & 1.504 & 0.665 & 5.112 & 0.121 & 0.332 & 4.921 & 0.022 \\
\hline OCF & 1.451 & 0.689 & 13.649 & 0.446 & 3.357 & 16.334 & 0.002 \\
\hline TACC & 1.404 & 0.712 & 5.745 & 0.311 & 1.112 & 6.112 & 0.024 \\
\hline Auto-correlation & & & & & & Regressic & \\
\hline Durbin-Watson & $\mathrm{R}^{2}$ & Adjusted $\mathrm{R}^{2}$ & & Standard & & $\mathrm{F}$ & P-value \\
\hline 1.986 & 0.392 & 0.387 & & 8.12601 & & 14.195 & 0.000 \\
\hline
\end{tabular}

Based on the results of Table 5, we can understand that F-value lies within the acceptable limit and we can conclude that there is a linear relationship between independent variables and dependent variable. In addition, t-student value is statistically meaningful, which means we can reject the null hypothesis and Durbin-Watson (1.986) remains within an acceptable limit leaving us to conclude that there is no auto correlation between residuals. The coefficient of accrual is 5.745 , which is less than the coefficient of operating cash flow (13.649), which means that there is a meaningful different between accrual and operating cash flow for describing cash cycle. Therefore, we can reject the null hypothesis.

$\mathrm{H}_{0}$ : There is no meaningful relationship between simultaneous use of total accruals and total operating cash flow and cash cycle.

$\mathrm{H}_{1}$ : There is no meaningful relationship between simultaneous use of total accruals and total operating cash flow and cash cycle.

As we can observe from the results of Table 5, the coefficients associated with growth profit, operating profit and net earnings are equal to 7.634, 21.423 and 5.112, respectively. Since all profit components include two components of cash and accrual and they are not greater than independent components of cash (13.649) and accrual (5.745) associated with earning per share, we cannot reject 
the null hypothesis and we cannot conclude that both cash and accrual terms to gether contribute to cash cycle.

\subsection{The fifth hypothesis}

There is a main hypothesis, which is as follows,

$\mathrm{H}_{0}$ : There is no meaningful relationship between the information obtained from total accruals compared with and total operating cash flow in relationship with debt ratio.

$\mathrm{H}_{1}$ : There is a meaningful relationship between information obtained from total accruals compared with total operating cash flow in relationship with debt ratio.

Table 6 demonstrates the proposed econometrics method as well as the results of our study using the implementation of ordinary least square.

\section{Table 6}

The results of regression model and the results of regression analysis for the firth hypothesis

\begin{tabular}{lllllll}
\hline \multicolumn{2}{l}{ Model DEBTRATIO } \\
\hline
\end{tabular}

Based on the results of Table 6, we can understand that F-value lies within the acceptable limit and we can conclude that there is a linear relationship between independent variables and dependent variable. In addition, t-student value is statistically meaningful, which means we can reject the null hypothesis and Durbin-Watson (1.728) remains within an acceptable limit leaving us to conclude that there is no auto correlation between residuals. The coefficient of accrual is 9.958, which is greater than the coefficient of operating cash flow (11.268), which means that there is a meaningful different between accrual and operating cash flow for describing debt ratio. Therefore, we can reject the null hypothesis.

$\mathrm{H}_{0}$ : There is no meaningful relationship between simultaneous use of total accruals and total operating cash flow and debt ratio.

$\mathrm{H}_{1}$ : There is no meaningful relationship between simultaneous use of total accruals and total operating cash flow and debt ratio.

As we can observe from the results of Table 6, the coefficients associated with growth profit, operating profit and net earning are equal to 12.613, 5.231 and 7.458, respectively. Since all profit components include two components of cash and accrual and they are different with independent components of cash (11.268) and accrual (9.958) associated with earning per share, we can reject the null hypothesis and conclude that both cash and accrual terms together contribute to debt ratio. 


\subsection{The sixth hypothesis}

There is a main hypothesis, which is as follows,

$\mathrm{H}_{0}$ : There is no meaningful relationship between the information obtained from total accruals compared with and total operating cash flow in relationship with P/E ratio.

$\mathrm{H}_{1}$ : There is a meaningful relationship between information obtained from total accruals compared with total operating cash flow in relationship with $\mathrm{P} / \mathrm{E}$ ratio.

Table 7 demonstrates the proposed econometrics method as well as the results of our study using the implementation of ordinary least square.

\section{Table 7}

The results of regression model and the results of regression analysis for the sixth hypothesis

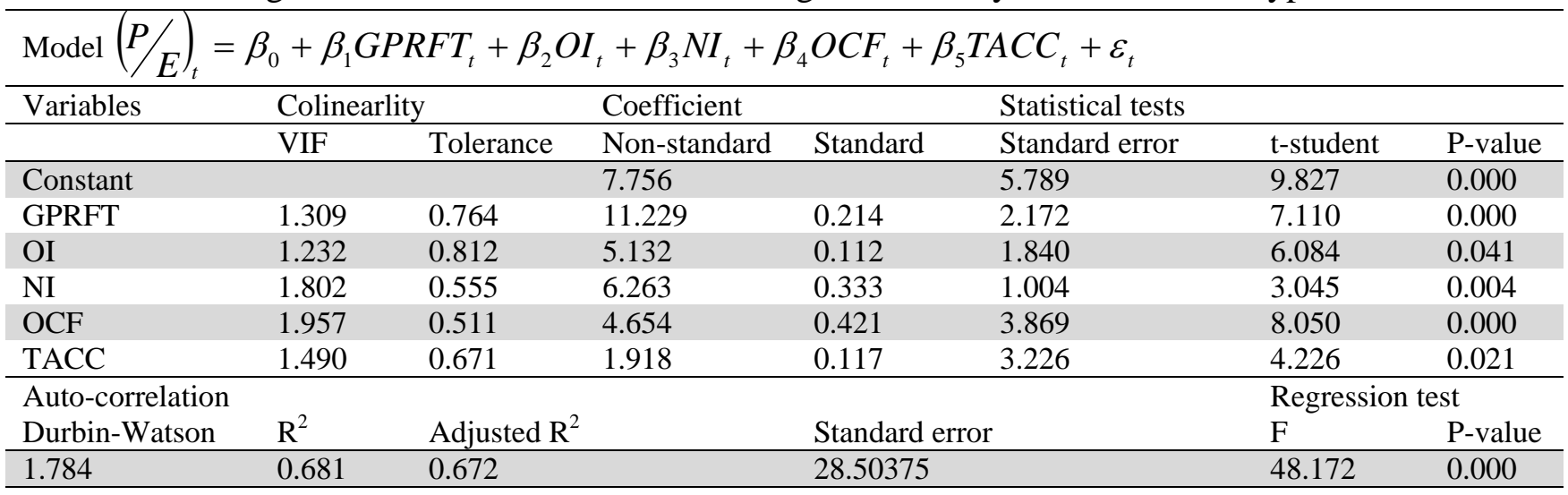

Based on the results of Table 7, we can understand that F-value lies within the acceptable limit and we can conclude that there is a linear relationship between independent variables and dependent variable. In addition, t-student value is statistically meaningful, which means we can reject the null hypothesis and Durbin-Watson (1.784) remains within an acceptable limit leaving us to conclude that there is no auto correlation between residuals. The coefficient of accrual is 1.918, which is less than the coefficient of operating cash flow (4.654), which means that there is a meaningful different between accrual and operating cash flow for describing debt ratio. Therefore, we can reject the null hypothesis.

$\mathrm{H}_{0}$ : There is no meaningful relationship between simultaneous use of total accruals and total operating cash flow and $\mathrm{P} / \mathrm{E}$ ratio.

$\mathrm{H}_{1}$ : There is no meaningful relationship between simultaneous use of total accruals and total operating cash flow and $\mathrm{P} / \mathrm{E}$ ratio.

As we can observe from the results of Table 3, the coefficients associated with growth profit, operating profit and net earnings are equal to 11.229, 5.132 and 6.263, respectively. Since all profit components include two components of cash and accrual and they are different with independent components of cash (4.654) and accrual (1.918) associated with earning per share, we can reject the null hypothesis and conclude that both cash and accrual terms together contribute to P/E ratio. 


\section{Conclusion}

In this paper, we have presented an empirical survey to study the role of accruals and operating cash flows on users' decisions on financial statements. The proposed study of this paper used data from a case study of Tehran stock exchange. The results of this research indicated that there was a significant different between accruals and operating cash flows information content in association to different decision-making criteria but utilizing accruals and operating cash flows supplementary and simultaneously in profit frame depending on the selection criteria may or may not include valueadded information.

\section{References}

Arabzadeh, M. (2012). A study on effects of cost-of-equity models on cost-of-capital and capital structure. Management Science Letters, 2(6), 1855-1864.

Hassani, M., \& Taheri, F. (2012). The role of earnings management and dividend announcement in explanation of information asymmetry: Evidence from Tehran Stock Exchange. Management Science Letters, 2(7), 2537-2544.

Khodaei Valahzaghard, M., \& Salehi, A. (2012). Impact of the corporate governance characteristics and ownership on earnings quality of the Islamic private banks in Iran. Management Science Letters, 2(7), 2607-2614

Panahian, H., Ghodrati, H., \& Nazari, M. (2012). Innate and discretionary accruals quality and corporate governance: A case study of Tehran Stock Exchange. Management Science Letters, 2(8), 3023-3030.

Rezaei, I., Delghandy, A., \& Miri, S.H. (2012). A study on the effect of board of directors on the rate of corporate transparency. Management Science Letters, 2(7), 2441-2448.

Raei, R., \& Bahrani Jahromi, M. (2012). Portfolio optimization using a hybrid of fuzzy ANP, VIKOR and TOPSIS. Management Science Letters, 2(7), 2473-2484.

VakilAlroaia, Y., \& Nabavi, S.R., \& Eslami Mofidabadi, H. (2012). Surveying effects of forwardbackward P/E ratios on stock's return and fluctuation in Tehran's stock exchange. Management Science Letters, 2(7), 1731-1740. 